\title{
Article \\ Microstructural, Electrochemical and In Vitro Analysis of Mg-0.5Ca-xGd Biodegradable Alloys
}

\author{
Bogdan Istrate ${ }^{1}\left(\mathbb{D}\right.$, Corneliu Munteanu ${ }^{1,2, *} \mathbb{C}$, Ramona Cimpoesu ${ }^{3, *}$, Nicanor Cimpoesu $^{3}$, Oana Diana Popescu ${ }^{1}$ (D) \\ and Maria Daniela Vlad ${ }^{4, *}$ \\ 1 Mechanical Engineering Department, Gheorghe Asachi University of Iasi, 6 D. Mangeron Blvd, \\ 700050 Iasi, Romania; bogdan_istrate1@yahoo.com (B.I.); diana3popescu@gmail.com (O.D.P.) \\ 2 Technical Sciences Academy of Romania, 26 Dacia Blvd, 030167 Bucharest, Romania \\ 3 Faculty of Material Science and Engineering Department, Gheorghe Asachi University of Iasi, 41 Dimitrie \\ Mangeron Str., 700050 Iasi, Romania; nicanor.cimpoesu@tuiasi.ro \\ 4 Faculty of Medical Bioengineering, Grigore T. Popa University of Medicine and Pharmacy from Iasi, 9-13 \\ Kogălniceanu Str., 700454 Iasi, Romania \\ * Correspondence: cornelmun@gmail.com (C.M.); ramona.cimpoesu@tuiasi.ro (R.C.); \\ maria.vlad@umfiasi.ro (M.D.V.); Tel.: +40-744-647-991 (C.M.); +40-743-646-660 (R.C.); \\ +40-746-100-851 (M.D.V.)
}

check for updates

Citation: Istrate, B.; Munteanu, C.; Cimpoesu, R.; Cimpoesu, N.; Popescu, O.D.; Vlad, M.D. Microstructural, Electrochemical and In Vitro Analysis of Mg-0.5Ca-xGd Biodegradable Alloys. Appl. Sci. 2021, 11, 981. https://doi.org/10.3390/app11030981

Received: 22 December 2020

Accepted: 15 January 2021

Published: 22 January 2021

Publisher's Note: MDPI stays neutral with regard to jurisdictional claims in published maps and institutional affiliations.

Copyright: (C) 2021 by the authors. Licensee MDPI, Basel, Switzerland. This article is an open access article distributed under the terms and conditions of the Creative Commons Attribution (CC BY) license (https:// creativecommons.org/licenses/by/ $4.0 /)$.

\begin{abstract}
The subject of Mg-based biodegradable materials, used for medical applications, has been extensively studied throughout the years. It is a known fact that alloying $\mathrm{Mg}$ with biocompatible and non-toxic elements improves the biodegradability of the alloys that are being used in the field of surgical applications. The aim of this research is to investigate the aspects concerning the microstructure, electrochemical response (corrosion resistance) and in vitro cytocompatibility of a new experimental $\mathrm{Mg}$-based biodegradable alloy- $\mathrm{Mg}-0.5 \% \mathrm{Ca}$ with controlled addition of Gd as follows: $0.5,1.0,1.5,2.0$ and $3.0 \mathrm{wt} . \%$-in order to establish improved biocompatibility with the human hard and soft tissues at a stable biodegradable rate. For this purpose, scanning electron microscopy (SEM), energy-dispersive spectroscopy (EDS), light microscopy (LM) and Xray diffraction (XRD) were used for determining the microstructure and chemical composition of the studied alloy and the linear polarization resistance (LPR) method was used to calculate the corrosion rate for the biodegradability rate assessment. The cellular response was evaluated using the 3-(4,5-dimethyltiazol-2-yl)-2,5-diphenyl tetrazolium bromide (MTT) test followed by fluorescence microscopy observation. The research led to the discovery of a dendritic $\alpha-\mathrm{Mg}$ solid solution, as well as a lamellar $\mathrm{Mg}_{2} \mathrm{Ca}$ and $\mathrm{Mg}_{5} \mathrm{Gd}$ intermetallic compound. The in vivo tests revealed $73-80 \%$ viability of the cells registered at 3 days and between 77 and $100 \%$ for 5 days, a fact that leads us to believe that the experimental studied alloys do not have a cytotoxic character and are suitable for medical applications.
\end{abstract}

Keywords: Mg-Ca-Gd alloys; SEM; EDS; microstructure; electrochemical evaluation; in vitro test

\section{Introduction}

Magnesium and its alloys are widespread in various fields such as human and veterinary medicine, and automotive and aerospace engineering, due to their superior properties in terms of biocompatibility, low modulus of elasticity, vibration damping and biodegradation capacity without side effects [1,2]. Medical applications that use biodegradable alloys based on $\mathrm{Mg}$, $\mathrm{Zn}$ or Fe are widespread, especially for orthopedic and cardiovascular surgical applications, leading scientific research to confirm that these alloys are hierarchical in scale as opposed to their alloy successors such as stainless steel, Co-Cr alloys and Ti-based alloys [3]. Mg-based biodegradable materials are used in the manufacture of screws, plates, scaffolds, etc. due to their similar modulus of elasticity to the biological bone and the biodegradable character which contributes to the general healing process $[4,5]$. 
In addition to orthopedic applications in the form of pins, screws, rods and plates, $\mathrm{Mg}$ alloys have been investigated in cardiovascular applications as biodegradable $\mathrm{Mg}$ alloy stents [6-11] due to their biodegradability and mechanical properties. In addition, the ideal cardiovascular stent biomaterial should promote endothelialization with minimal neo-intimal hyperplasia. In this sense, any kind of injury caused by the implantation of the biomaterial into the living tissue will initiate an inflammatory reaction to the material, with fibroblasts being a key contributor to new tissue formation post-injury (i.e., depositing new collagen and facilitating healing or fibrous encapsulation), even though it may not necessarily be in direct contact with the implanted cardiovascular devices. Unfortunately, biodegradable magnesium-based alloys also have a number of disadvantages, such as low corrosion resistance and high hydrogen release during bone healing, which can cause subcutaneous inflammatory reactions $[12,13]$. Furthermore, the presence of various impurities that accompany the manufacturing process of these materials, such as $\mathrm{Fe}, \mathrm{Ni}, \mathrm{Cu}$, etc., at very low concentrations leads to a decrease in biocompatibility and a lack of corrosion properties [14,15]. In order to improve these aspects, scientific studies have continued to combine $\mathrm{Mg}$ with biocompatible elements that do not produce toxic effects $(\mathrm{Ca}, \mathrm{Sr}, \mathrm{Mn}$, etc.), but also rare earth (RE) elements [16]. The conceptual alloy design for these alloys with elements of the rare earth category was based on the necessity and improvement of the properties of $\mathrm{Mg}-\mathrm{Ca}, \mathrm{Mg}-\mathrm{Sr}$ and $\mathrm{Mg}-\mathrm{Mn}$ systems, etc., by increasing mechanical resistance, decreasing density and improving the rate of degradation in environments such as simulated biological fluids. Wu et al. [17] and Zhang et al. [18] established that rare earth elements are divided into two classes: light RE elements (Y, Ce, La, etc.) and heavy RE elements (Gd, Sm, Sc, etc.) and research conducted by Liu et al. identified that some of the most effective alloys used in the medical field are the $\mathrm{Mg}-\mathrm{Gd}$ and $\mathrm{Mg}-\mathrm{Y}$ binary alloys [19]. Gadolinium (Gd) presents a solubility of $23.49 \mathrm{wt} . \%$ at the eutectic temperature [20] in $\mathrm{Mg}$ and plays a key role in strengthening the solid solution when alloyed to Mg. Feyerabend et al. identified that $\mathrm{Gd}$ is one of the rare earth elements with the best biocompatibility of all REEs (rare earth elements) [21]. Hort et al. [22] noted that the Mg-Gd binary system has mechanical properties very close to those of the biological bone compared with the conventional biocompatible $\mathrm{Co}-\mathrm{Cr}$ and Ti alloys. Gao et al. [23] investigated the effects of Gd on a solid solution and reported that it was an effective solid solution enhancer in $\mathrm{Mg}$ compared with $\mathrm{Al}$ and $\mathrm{Zn}$. Studies conducted by Peng et al. [24] suggested that the molten Mg-20Gd alloy contained mostly the supersaturated $\alpha$-Mg solid solution, while the as-cast Mg-20Gd alloy consisted of $\alpha-\mathrm{Mg}+\mathrm{Mg} 5 \mathrm{Gd}$. Nodooshan et al. [25] showed that increasing Gd will lead to the age-hardening response and tensile strength of $\mathrm{Mg}-\mathrm{xGd}-\mathrm{Y}-$ $\mathrm{Zr}(\mathrm{x}=3 \mathrm{wt} . \%, 6 \mathrm{wt} . \%, 10 \mathrm{wt} . \%, 12 \mathrm{wt} . \%)$ alloys and developed a Mg-10Gd3Y-0.5Zr alloy with an ultimate tensile strength of $390 \mathrm{MPa}$ and a yield strength of $245 \mathrm{MPa}$. Gao et al. [23] published that the properties of Mg alloys had been improved by the addition of REEs due to the formation of metastable REEs containing phases along the grain boundaries. Alloying with Gd more than $10 \mathrm{wt} . \%$ increases the mechanical strength due to the noble behavior of Mg5Gd precipitated in grain boundaries. Research findings have also shown that $\mathrm{Gd}$ improves the rate of degradation of $\mathrm{Mg}$ alloys by stabilizing the resulting corrosion products [26], but at concentrations greater than $5 \mathrm{wt} . \%$, the rate of degradation and biocompatibility could decrease. At the same time, Myrissa et al. [27] highlighted the corrosion resistance of the $\mathrm{Mg}-10 \mathrm{Gd}$ alloy implanted in rats and observed that alloys with a high percentage of $\mathrm{Gd}(10 \mathrm{wt} . \%)$ implanted for up to 36 weeks led to increased concentrations of Gd in various rat organs, such as the spleen, liver, lung and kidney. Among several other alloy elements, calcium (Ca) improves the biocompatibility and mechanical properties of magnesium-based alloys $[28,29]$. Additionally, the most major issue for the application of $\mathrm{MgCa}$ as implantable elements is still the high corrosion and electro-corrosion rate in body fluids [30-32]. Percentages higher than $1 \mathrm{wt} . \%$ Ca have also been shown to reduce certain characteristics such as castability, corrosion behavior and mechanical properties due to the higher volume fraction of the $\mathrm{Mg}_{2}$ Ca phases [33,34], which also has an effect on the biocompatibility of the alloy [35]. Maradze et al. presented in their studies that the 
report through $\mathrm{Mg}^{2+}$ and $\mathrm{Ca}^{2+}$ ions has an important part to play in the maintenance of the cellular activities of the embryonic mesenchymal cells that give rise to striated muscle fibers [36]. Upon first contact of multi-nucleated fibers with high $\mathrm{Mg}$ and $\mathrm{Mg}-\mathrm{Ca}$ corrosion compounds, the effect was to reduce cell viability, while at the same time the myotubes became capable of adaptation. A significant percentage of $\mathrm{Mg}^{2+}$ ions can substantially increase cell proliferation and, at the same time, the presence of $\mathrm{Ca}^{2+}$ ions is extremely important for the formation of fibers [37]. The properties of $\mathrm{Mg}-\mathrm{Ca}$ alloys are affected by mechanical or thermo-mechanical processing [38-40]. Therefore, alloying the $\mathrm{Mg}-\mathrm{Ca}$ alloys $(<1 \mathrm{wt} . \% \mathrm{Ca})$ with a third element, such as Gd, can be the right path to follow in order to improve the mechanical properties and biocompatibility of the alloy being studied in this paper. In this research paper, the authors studied a novel $\mathrm{Mg}-0.5 \mathrm{wt} . \%$ Ca experimental material which was alloyed with a controlled content of $0.5,1.0,1.5,2.0$ and $3.0 \mathrm{wt} . \% \mathrm{Gd}$ in order to improve the biodegradability rate needed for a symmetrical balance between alloy degradation and bone healing, followed by in vitro 3-(4,5-dimethyltiazol-2-yl)-2,5-diphenyl tetrazolium bromide (MTT) tests to determine its biocompatibility.

\section{Experimental Details}

2.1. Obtaining theMagnesium with Calcium and Gadolinium Alloys' Structure and Chemical Composition Investigations

The manufacturing process of the experimental alloys used master alloys procured from Hunan China Co. [41,42] with the mass percentages shown in Table 1. The Mg-based alloys were obtained through a classical melting process using an induction furnace in an Ar-protected environment in a $675-700{ }^{\circ} \mathrm{C}$ temperature field for 30 minutes from a square section of the initial materials, as in previous research [43]. The elaboration process resulted in cylindrical mini-ingots, which were cut in smaller round plates with different chemical compositions based on the differences between the Gd element concentrations, with the values shown in Table 2. The round samples are $20 \mathrm{~mm}$ in diameter with a thickness of $2 \mathrm{~mm}$. Material load calculations were made on the basis of the metal loss coefficient; the quantities used are shown in Table 2 (with specimen codes) with a net mass of around $23 \mathrm{~g}$ per melt. For experimental tests, the specimens were mechanically polished with an $\mathrm{Al}_{2} \mathrm{O}_{3}$ suspension solution $(2-5 \mu \mathrm{m})$ after metallographic grinding with paper disks of $200-2500 \mathrm{MPi}$ granulation. The surface was cleaned with ethylalcohol for $30 \mathrm{~min}$ and the microstructure was highlighted by chemical etching using $\mathrm{Mg}\left(\mathrm{CH}_{3} \mathrm{COO}\right) 2 \mathrm{Mg} \cdot 4 \mathrm{H}_{2} \mathrm{O}$ acetate solution. Microstructural aspects were analyzed by optical microscopy (Leica DMI 5000 equipment, Leica, Wetzlar, Germany) and scanning electron microscopy (SEM)(FEI Quanta 200 3D). Chemical composition determinations were accomplished with an energy-dispersive spectroscopy (EDS) detector (Xflash, Bruker, Germany) and a X-ray diffractionsystem (XRD) (Xpert PRO MPD 3060 equipment, Panalytical, The Netherlands; copper-X-ray tube $\left.\left(\mathrm{K} \alpha=1.54051^{\circ}\right), 2 \theta: 20^{\circ}-100^{\circ}\right)$.

Table 1. Magnesium and Mg-based master alloy weight percentages [41,42].

\begin{tabular}{ccccccc}
\hline Materials & $\begin{array}{c}\mathrm{Mg} / \mathrm{Ca} / \mathrm{Gd} \\
\text { (wt.\%) }\end{array}$ & $\begin{array}{c}\mathrm{Fe} \\
\text { (wt.\%) }\end{array}$ & $\begin{array}{c}\text { Ni } \\
\text { (wt.\%) }\end{array}$ & $\begin{array}{c}\mathrm{Cu} \\
\text { (wt.\%) }\end{array}$ & $\begin{array}{c}\text { Si } \\
\text { (wt.\%) }\end{array}$ & $\begin{array}{c}\text { Al } \\
\text { (wt.\%) }\end{array}$ \\
\hline Pure $\mathrm{Mg}$ & $\mathrm{Mg}(99$ wt.\%) & $0.15-0.2$ & $0.17-0.2$ & $0.14-0.2$ & $0.15-0.2$ & $0.16-0.2$ \\
Mg15Ca & $\mathrm{Ca}(15.29$ wt.\%) & 0.004 & 0.001 & 0.003 & 0.013 & 0.011 \\
Mg30Gd & Gd (28.05 wt.\%) & 0.010 & 0.001 & 0.001 & 0.006 & 0.011 \\
\hline
\end{tabular}


Table 2. Initial materials masses used formetal charges in order to obtain the experimental samples.

\begin{tabular}{ccccc}
\hline Specimens & $\begin{array}{c}\text { Chemical } \\
\text { Composition }\end{array}$ & Mg [Grams] & $\begin{array}{c}\text { Mg-15Ca } \\
\text { (Grams) }\end{array}$ & $\begin{array}{c}\text { Mg-30Gd } \\
\text { (Grams) }\end{array}$ \\
\hline MgCa0.5Gd & Mg-0.5\%Ca-0.5\%Gd & 21.82 & 0.77 & 0.41 \\
MgCa1Gd & Mg-0.5\%Ca-1\%Gd & 21.42 & 0.77 & 0.82 \\
MgCa1.5Gd & Mg-0.5\%Ca-1.5\%Gd & 21.00 & 0.77 & 1.23 \\
MgCa2Gd & Mg-0.5\%Ca-2\%Gd & 20.59 & 0.77 & 1.64 \\
MgCa3Gd & Mg-0.5\%Ca-3\%Gd & 19.77 & 0.77 & 2.46 \\
\hline
\end{tabular}

\subsection{Electrochemical Analysis}

Based on the protocol applied in [43], the experimental magnesium-based alloys' behavior was tested in simulated body fluid (SBF) electrolyte with the ion composition as shown in Table 3. An electro-corrosion resistance VoltaLab-21 potentiostat (Radiometer, Denmark) was used to analyze linear and cyclic curve determinations in SBF. The results were acquired and processed using the Volta Master 4 program package. For experiments, an experimental cell was used to expose the sample (work electrode) to an electrolyte solution at the same time with the Pt auxiliary electrode and a calomel-saturated one. The samples were isolated with Teflon, so only a specific area was exposed to the electrolyte, namely $0.78 \mathrm{~cm}^{2}$. The solution was permanently aerated with a magnetic stirrer in order to remove the gas bubbles formed on the metal surface due to hydrogen elimination. Electrochemical polarization test methods established the criteria for susceptibility for several forms of corrosion and anodic or cathodic protection. Cyclic voltammetry, potentiodynamic and potentiostatic techniques were necessary for evaluation of the passive region, aptitude to passivation, stability and quality of passivation (corrosion rate).

Table 3. Ions composition of the simulated body fluid(SBF)electrolyte used for experiments [44].

\begin{tabular}{|c|c|c|c|c|c|c|c|c|}
\hline Electrolyte Ions (mmol/dm ${ }^{3}$ ) & $\mathrm{Na}^{+}$ & $\mathbf{K}^{+}$ & $\mathrm{Mg}^{2+}$ & $\mathrm{Ca}^{2+}$ & $\mathrm{Cl}^{-}$ & $\mathrm{HCO}_{3}^{-}$ & $\mathrm{HPO}_{4}{ }^{2-}$ & $\mathrm{SO}_{4}^{2-}$ \\
\hline Simulated body fluid & 142 & 5 & 1.5 & 2.5 & 147.8 & 4.2 & 1 & 0.5 \\
\hline Human blood plasma & 142 & 5 & 1.5 & 2.5 & 103 & 27 & 1 & 0.5 \\
\hline
\end{tabular}

Direct current (DC) electrochemistry, particularly the potentio-dynamic polarization test, was used to record much relevant information based on the behavior of the electrodes. Using direct current polarization mechanisms, we could obtain detailed information about the working electrodes' (MgCaGd samples) corrosion rate and the type of surface corrosion: generalized or pitting, passivation layer formation and stability, and anodic (oxidation) or cathodic (reduction) reactions. The linear polarization resistance method is probably one of the most widespread applications of electrochemical measurements in the laboratory and is widely applied in the case of uniform (generalized) corrosion.

The following coordinates were chosen by the authors for the function representation: current density $\left[\mathrm{mA} / \mathrm{cm}^{2}\right]$ and potential $[\mathrm{V}]$, because this variation allows emphasis on the corrosion potential $\left(E_{0}\right)$ and corrosion current $\left(J_{\text {corr }}\right)$. The experiments were realized at room temperature $\left(24^{\circ} \mathrm{C}\right)$ and the potential records were registered (linear plots were registered at a scan rate of $1 \mathrm{mV} / \mathrm{s}$ and the cyclic plots at a scanning rate of $10 \mathrm{mV} / \mathrm{s}$ ). The tests were repeated 4times to achieve proper repeatability of the results. The corrosion current density, $J_{c o r r}$, can be determined using 2 equations by extrapolation of the Tafel lines: a complete polarization curve consisting of a cathodic part and an anodic part. The cathodic portion of the polarization curve contains information concerning the kinetics of the reduction reactions occurring for a particular system.

The corrosion potential is deduced from the intersection of the anodic and cathodic Tafel slopes. 
This method is based on polarization resistance evaluation, $\mathrm{Rp}$, which is defined as the tangent slope of the potential-current density curve $[E=f(j)]$ at the equilibrium point $\left(E=E_{0}\right)$, indicating the free corrosion potential:

$$
R_{p}=\left[\frac{\Delta E}{\Delta j}\right]_{E=E_{0}} \mathrm{ohm} \cdot \mathrm{cm}^{2}
$$

Corrosion current values were used to obtain the instantaneous corrosion rate: $V_{\text {corr }}$ $(\mu \mathrm{m} /$ year $)$ :

$$
\begin{gathered}
V_{\text {corr }}=22.9 \cdot J_{c o r r} \\
J_{c o r r}=\frac{b_{a} \cdot b_{c}}{2.303\left(b_{a}+b_{c}\right) \cdot R_{p}^{\prime}}\left(\mathrm{mA} / \mathrm{Scm}^{2}\right)
\end{gathered}
$$

\subsection{Cytocompatibility Analysis}

\subsubsection{Alloy Sample Preparation}

The alloy specimens with the appearance of flat samples (with a mean weight of $0.83 \mathrm{~g}$ ) were sonicated in an acetone-ethanol mix in order to eliminate impurities, sterilized under ultraviolet (UV) light for a time interval of $30 \mathrm{~min}$ on each side ( 3 samples for each studied alloy) and subsequently placed in well-permeable supports (with a $0.4-\mu \mathrm{m}$ pore membrane insert) in order to co-incubate them with the cells for the cellular viability study.

\subsubsection{Cell Culture}

For the cell viability study, we used albino rabbit dermal primary fibroblasts (passage No. 3) cultured in a complete Dulbecco's modified Eagle medium/Nutrient F-12 Ham (DMEM-F12 Ham) culture medium. For this, 10\% inactivated fetal bovine serum (FBS) and $1 \%$ antibiotic solution (containing 5000 units penicillin, $5 \mathrm{mg}$ streptomycin and $10 \mathrm{mg}$ neomycin $/ \mathrm{mL}$ ) were added to the cell culture media prior to use, and the cells were kept under standard cell culture conditions (i.e., a humid incubator at $37^{\circ} \mathrm{C}$ and $5 \% \mathrm{CO}_{2}$ ). Briefly, after attaining the $90 \%$ confluence level, the cells were washed with phosphate-buffered saline (PBS) solution, detached by incubation with trypsin/EDTA (Sigma Chemical Co., St. Louis, MA, USA), used for seeding in 24-well culture plates at a density of $1 \times 10^{4}$ cells/well and then incubated for $24 \mathrm{~h}$ to facilitate cell adhesion on the wells' bottom. Subsequently, the medium was changed with complete fresh medium, after eliminating the unattached or dead cells by washing with PBS [44,45]. Afterwards, the experimental $\mathrm{Mg}$ alloy samples placed in well-permeable supports were suspended on the top of the 24-well-plated cell cultures and co-incubated under the abovementioned conditions for 1, 3 and 5 days. The medium was refreshed every 2 days. A similar methodology was applied for both the cytocompatibility assay and the cell morphology evaluation [46]. It should be pointed out that our method favored the interaction/reaction between the studied $\mathrm{Mg}$ alloys with the cell culture medium [47]. In this study, we used control wells (i.e., negative controls) containing cell cultures only (i.e., 3 control wells for each time period).

\subsubsection{Cell Viability}

The alloys' cytocompatibility was evaluated by the 3-(4,5-dimethyltiazol-2-yl)-2,5diphenyl tetrazolium bromide (MTT) colorimetric assay [35], similar to in the literature [37,38], which allows quantification of the live cells' metabolic activity. The cell viability study was done through direct co-incubation of the cells with the studied $\mathrm{Mg}$ alloy samples (i.e., continuous cell exposition to an $100 \%$ extract) but avoiding cell mechanical injury as a consequence of the $\mathrm{Mg}$ alloys disintegrating by dangling the permeable supports, containing the metal samples, into the 24-wellplates. Briefly, after established incubation periods (i.e., 1, 3 and 5 days), the permeable supports were removed from the wells and the cells were treated with a MTT dye solution (for $3 \mathrm{~h}$ at $37^{\circ} \mathrm{C}$ ) in order to facilitate intracellular formazan crystal formation. Subsequently, the solubilization of the insoluble dark-blue formazan product was performed with isopropyl alcohol by continuous 
agitation for 15 min using an Environmental Shaker-Incubator (type ES-20, Biosan, Riga, Latvia). The characteristic absorbance of each well was read at a wavelength of $570 \mathrm{~nm}$ using a microplate reader (Tecan Sunrise, with Magellan V.7.1 data processing software). The cell viability data for the studied Mg alloys were expressed as a percentage of the cell viability data related to the controlwells by means of the formula: cellular viability = $100 \times$ (alloy wells' optical density-empty wells' optical density)/(control wells' optical density - empty wells' optical density). The one-way ANOVA test was used for statistical analysis of cell viability data; Tukey's method was used for comparing the obtained results and statistically significant differences were accepted at $p<0.05$.

\subsubsection{Cell Morphology}

For fluorescence staining, after co-incubation periods of 1 and 5 days (under the conditions explained in the sections above), the cells in each well were rinsed with Hanks' Balanced Salt solution (HBSS) (H8264, Sigma-Aldrich, St. Louis, MO, USA) without red phenol, then $200 \mu \mathrm{L}$ of a 1:1000 calcein solution (Calcein AM; C1359, Sigma-Aldrich)was added in HBSS. After incubation for $30 \mathrm{~min}$, in the dark and at $37^{\circ} \mathrm{C}$, the cells' morphology and distribution were investigated through visualization and image acquisition using an inverted microscope (Leica DMIL LED equipped with a Leica DFC450C camera and Leica Application Suite-Version 7.4.1 image acquisition software, Leica, Wetzlar, Germany).

\section{Results and Discussions}

\subsection{Microstructural Analysis}

The morphological and microstructural analysis of $\mathrm{Mg}-0.5 \mathrm{Ca}-\mathrm{xGd}$ alloys by light microscopy is presented in Figure 1. The microstructure typically exhibits aspects of as-melted metallic alloys with $\mathrm{Mg}_{2} \mathrm{Ca}$ tabular intermetallic structures and particles of $\mathrm{Mg}_{5} \mathrm{Gd}$ which are proportionally equably distributed. The enhancement with Gd shows the growth of round particles with a separation trend of somewhat uniformly distributed black dots [48]. The structural appearance of the SEM images of the said specimens is shown in Figure 2 and the existence of an intermetallic stage is noticeable. Gd-based compounds are usually acicular and round in shape and are observed to be whiter than the Mg2Ca tabular intermetallic compounds. Gd has a slightly low influence on the size and shape of $\mathrm{Mg}$ grains, confirmed by literature studies $[49,50]$ on $\mathrm{Mg}$-based alloys with a Gd content between 1 wt.\% and 4 wt.\%.
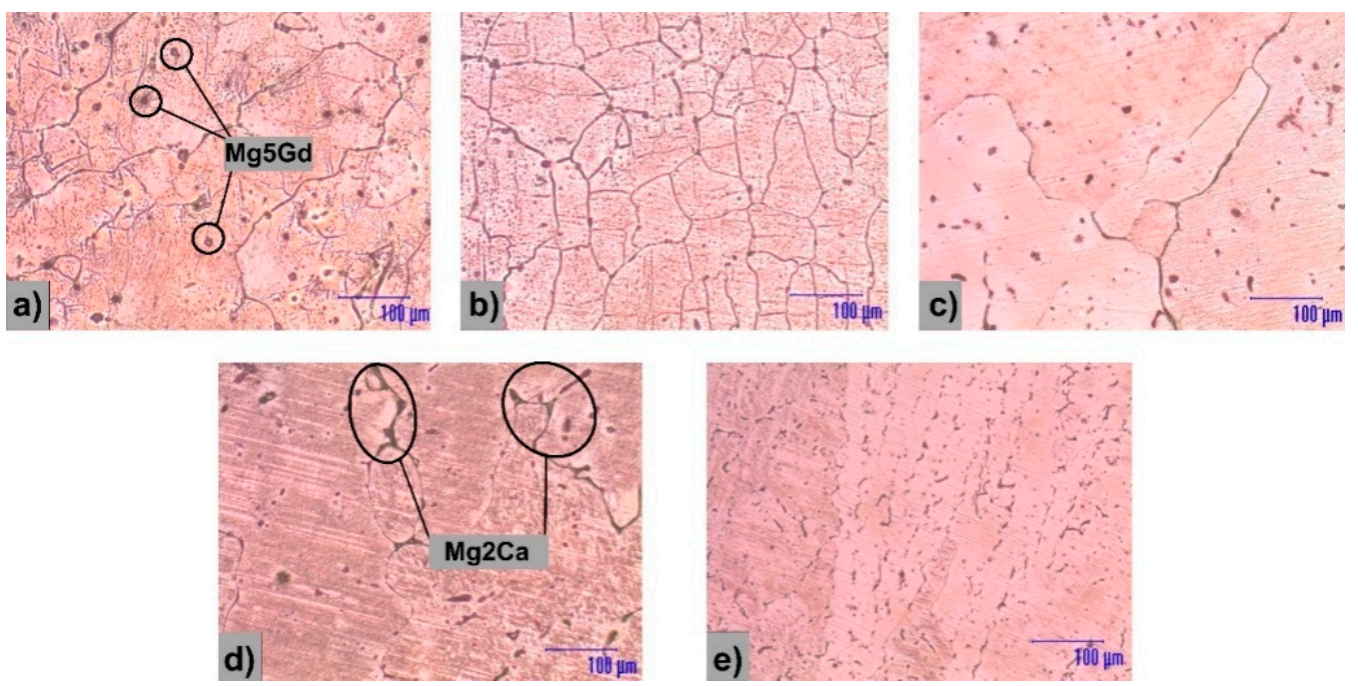

Figure 1. Optical images of samples: (a) $\mathrm{Mg}-0.5 \mathrm{Ca}-0.5 \mathrm{Gd}$; (b) $\mathrm{Mg}-0.5 \mathrm{Ca}-1 \mathrm{Gd}$; (c) $\mathrm{Mg}-0.5 \mathrm{Ca}-1.5 \mathrm{Gd}$; (d) $\mathrm{Mg}-0.5 \mathrm{Ca}-2 \mathrm{Gd}$; (e) Mg-0.5Ca-3Gd. 

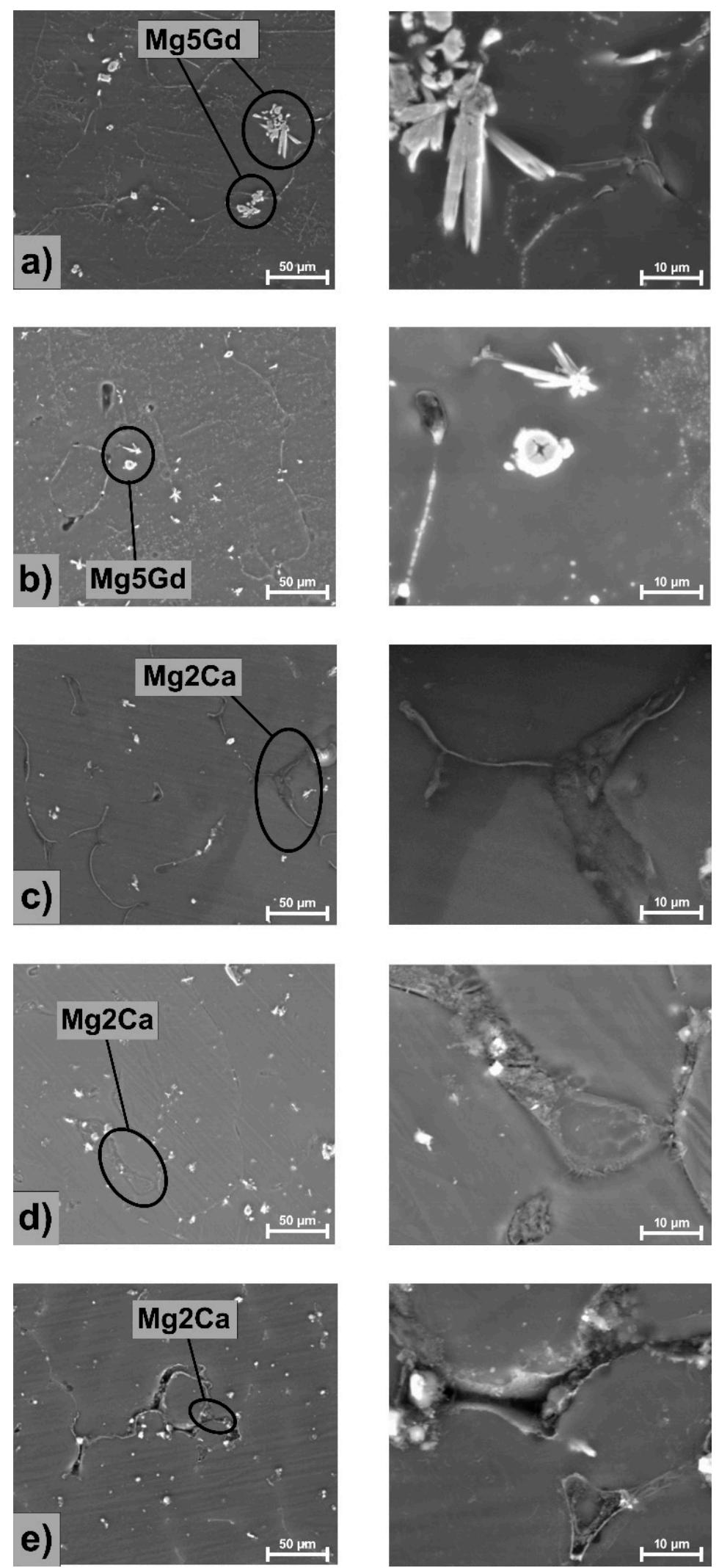

Figure 2. SEM images of the samples: (a) $\mathrm{Mg}-0.5 \mathrm{Ca}-0.5 \mathrm{Gd}$; (b) $\mathrm{Mg}-0.5 \mathrm{Ca}-1 \mathrm{Gd}$; (c) $\mathrm{Mg}-0.5 \mathrm{Ca}-1.5 \mathrm{Gd}$; (d) $\mathrm{Mg}-0.5 \mathrm{Ca}-2 \mathrm{Gd} ;$ (e) $\mathrm{Mg}-0.5 \mathrm{Ca}-3 \mathrm{Gd}$. 
The chemical composition of the $\mathrm{Mg}-0.5 \mathrm{Ca}-\mathrm{xGd}$ alloys was investigated by energy dispersive spectroscopy and is shown in Figure 3. Cross-sectional areas of the specimens were analyzed in 10 separate zones and the mean values are given.

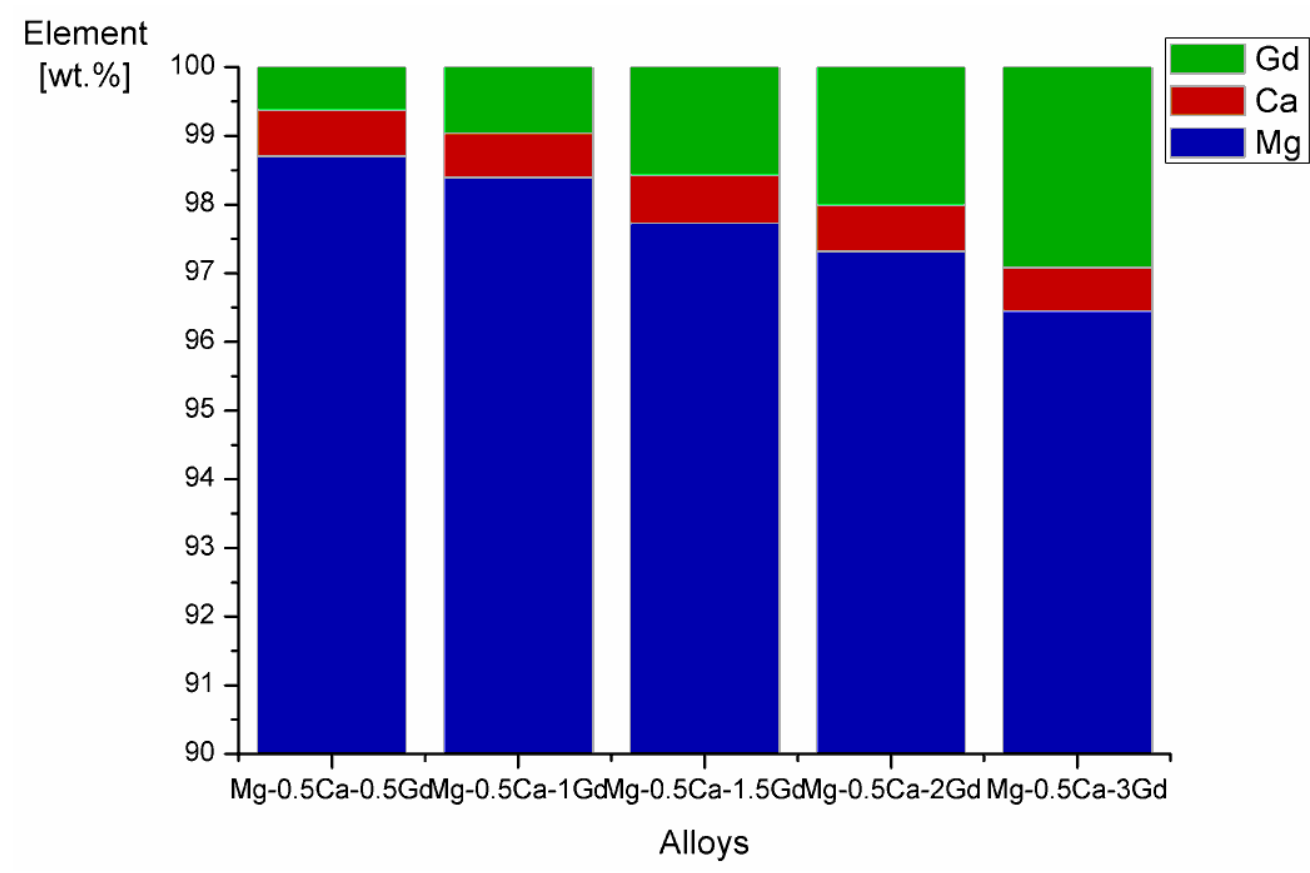

Figure 3. Average elemental composition obtained by energy-dispersive spectroscopy (EDS) analysis (SD Mg: $\pm 0.27, \pm 0.45, \pm 0.26, \pm 0.36, \pm 0.38$; SD Ca: $\pm 0.11, \pm 0.08, \pm 0.11, \pm 0.12, \pm 0.12 ;$ SD Gd: \pm 0.13 , $\pm 0.18, \pm 0.16, \pm 0.26, \pm 0.41)$.

The structural morphology investigation emphasizes homogeneous elements and the growth of peculiar phases, rated in a $\alpha$-Mg-based solid solution $(\alpha-\mathrm{Mg}), \mathrm{Mg}_{2} \mathrm{Ca}$ and $\mathrm{Mg}_{5} \mathrm{Gd}$. The $\mathrm{Mg}_{2} \mathrm{Ca}$ complex element is situated at the limits of the $\alpha-\mathrm{Mg}$ grains, realizing a film-coated eutectic with $\alpha$-Mg. X-ray diffraction peaks of the experimentally $\mathrm{Mg}-0.5 \mathrm{Ca}-$ $x \mathrm{Gd}$ alloys are given in Figure 4. From the XRD analysis shown in Figure 4, the $\mathrm{Mg}, \mathrm{Mg} 2 \mathrm{Ca}$ and Mg5Gd phases were detected in the X-ray diffraction peaks of the experimentally Mg-0.5Ca-xGd alloys. $\alpha-\mathrm{Mg}$ (ICDD-PDF-International Center for Diffraction Data-PDF: 01-071-9399) has been identified at different $2 \theta$ values $\left(30.24^{\circ}, 35.77^{\circ}, 46.82^{\circ}, 56.34^{\circ}\right.$ and $\left.77.62^{\circ}\right)$ as the main structure with a hexagonal crystalline phase. Moreover, the existence of $\mathrm{Mg}_{2} \mathrm{Ca}$ (ICDD-PDF: 01-073-5122) was shown at $2 \theta=34.86^{\circ}, 67.42^{\circ}$ and $96.88^{\circ}$, and $\mathrm{Mg}_{5} \mathrm{Gd}$ (ICDD-PDF: 01-071-9618) in a cubic system at $2 \theta=29.46^{\circ}, 61.15^{\circ}$ and $87.64^{\circ}$. As the Gd percentage gradually increased, the diffraction peak of $\mathrm{Mg} 5 \mathrm{Gd}$ intensified. The lattice parameters of the $\mathrm{Mg}-0.5 \mathrm{Ca}-\mathrm{xGd}$ alloy phases are presented in Table 4.

Table 4. Lattice parameters of $\mathrm{Mg}-0.5 \mathrm{Ca}-\mathrm{xGd}$ alloy phases.

\begin{tabular}{|c|c|c|c|c|c|c|c|c|c|c|}
\hline Compound & $\begin{array}{l}\text { Space } \\
\text { Group }\end{array}$ & $\begin{array}{l}\text { Crystal } \\
\text { System }\end{array}$ & a & $\begin{array}{c}\mathbf{b} \\
(\AA)\end{array}$ & $\begin{array}{c}\text { c } \\
(\stackrel{\AA}{)})\end{array}$ & $\begin{array}{c}\alpha \\
\left({ }^{\circ}\right)\end{array}$ & $\begin{array}{l}\beta \\
\left.{ }^{\circ}\right)\end{array}$ & $\begin{array}{l}\gamma \\
\left({ }^{\circ}\right)\end{array}$ & $\begin{array}{l}\text { Cell Volume } \\
\left(10^{6} \mu \mathrm{m}^{3}\right)\end{array}$ & RIR \\
\hline $\mathrm{Mg}$ & $\mathrm{P} 63 / \mathrm{mmc}$ & Hexagonal & 3.2089 & 3.2089 & 5.2101 & 90 & 90 & 120 & 46.46 & 4.01 \\
\hline $\mathrm{Mg}_{2} \mathrm{Ca}$ & $\mathrm{P} 63 / \mathrm{mmc}$ & Hexagonal & 6.2250 & 6.2250 & 10.1800 & 90 & 90 & 120 & 341.63 & 2.30 \\
\hline $\mathrm{Mg}_{5} \mathrm{Gd}$ & $\mathrm{F} 43 \mathrm{~m}$ & Cubic & 3.9500 & 3.9500 & 3.9500 & 90 & 90 & 90 & 61.63 & 18.05 \\
\hline
\end{tabular}




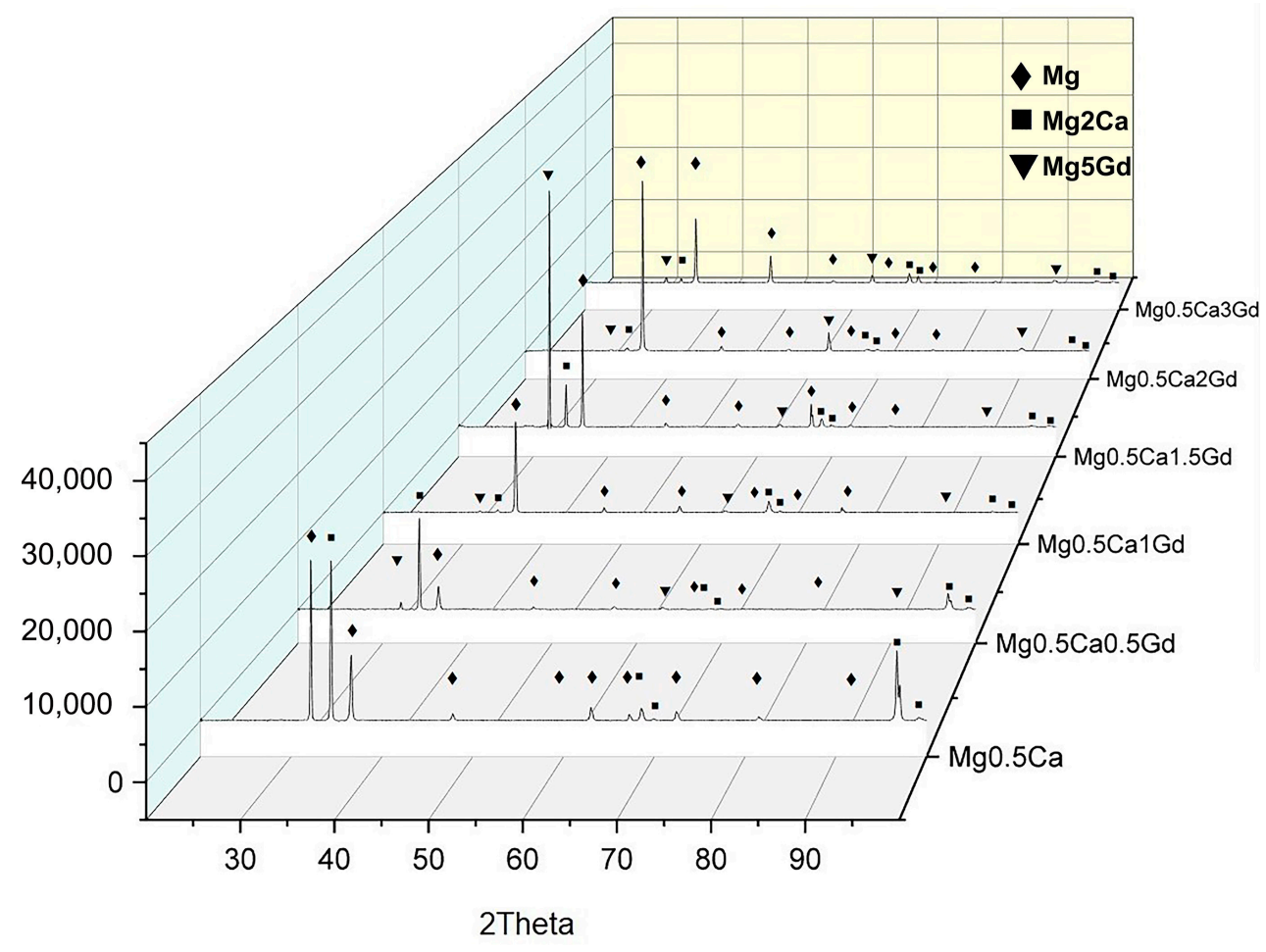

Figure 4. XRD pattern of $\mathrm{Mg}-0.5 \mathrm{Ca}-\mathrm{xGd}$ samples.

\subsection{Electrochemical Corrosion Resistance Analysis}

Normally, in the process of electrochemical corrosion, the cathodic polarization curve is assumed to represent the cathodic $\mathrm{H}_{2}$ evolution through solution reduction, while the anodic polarization curve represents the dissolution of the magnesium alloy.

The alloys in contact with the electrolyte solution present both anodic and cathodic reactions, with higher activity for oxidation process (in all cases $b_{a}>b_{c}$ ), with an increase in the difference at the beginning of Gd alloying (first three samples) and a drop in the differences between anodic and cathodic reactions for samples with 2 or $3 \mathrm{wt} . \% \mathrm{Gd}$. The highest oxidation rate was observed in the $\mathrm{Mg}-0.5 \mathrm{Ca}-1.5 \mathrm{Gd}$ samples and the lowest with the reduction reactions for the $\mathrm{Mg}-0.5 \mathrm{Ca}-0.5 \mathrm{Gd}$ sample. However, the rate of corrosion depended on the intensity of both reactions [51].

The experimental conditions of the electro-corrosion experiment realized in SBF electrolyte are given in Table 5. Because magnesium and magnesium-based alloys discharge large amounts of hydrogen into the exposed solution part of the sample, the gaseous gaps appear to be in the form of continuous bubbles [52]. Removal of the $\mathrm{H}_{2}$ voids from the metallic surface was realized with a magnetic stirrer at a controlled speed; in our case, we used a much-reduced rate of SBF shuffling in order to avoid the acceleration of the corrosion rate. After every determination, based on the fact that the electrolyte solution changed its color, a new quantity of SBF was used. At the contact with the SBF electrolyte solution, the metallic specimen presented an oxidation process to metal ions based on the following reactions:

$$
\begin{aligned}
\mathrm{Mg} & \rightarrow \mathrm{Mg}^{2+}+2 \mathrm{e}^{-} \\
\mathrm{Ca} & \rightarrow \mathrm{Ca}^{2+}+2 \mathrm{e}^{-}
\end{aligned}
$$

The electrons from the anodic reaction were consumed by a corresponding cathodic Reaction (4) and the reduction of oxygen dissolved in $\mathrm{H}_{2} \mathrm{O}$.

$$
2 \mathrm{H}_{2} \mathrm{O}+2 \mathrm{e}^{-} \rightarrow \mathrm{H}_{2}+2 \mathrm{OH}^{-}
$$


Table 5. Parameters obtained from the electro-corrosion resistance tests of the experimental alloys $\mathrm{Mg}-0.5 \mathrm{Ca}-\mathrm{xGd}(\mathrm{x}=0.5$; $1 ; 1.5 ; 2$ and 3 wt. \%).

\begin{tabular}{|c|c|c|c|c|c|c|c|}
\hline Sample & $\begin{array}{c}E_{0} \\
\mathrm{mV}\end{array}$ & $\begin{array}{c}b_{a} \\
\mathbf{m V}\end{array}$ & $\begin{array}{c}b_{c} \\
\mathrm{mV}\end{array}$ & $\begin{array}{c}R_{p} \\
\mathrm{ohm} \cdot \mathrm{cm}^{2}\end{array}$ & $\begin{array}{c}J_{\text {cor }} \\
\mu \mathrm{A} / \mathrm{cm}^{2}\end{array}$ & $\begin{array}{c}V_{c o r} \\
\mathrm{~mm} / \mathrm{Y}\end{array}$ & $\begin{array}{c}\text { OCP } \\
\mathrm{V}\end{array}$ \\
\hline $\mathrm{Mg}-0.5 \mathrm{Ca}$ & -3511.2 & 217.8 & -188.6 & 0.114 & 170.11 & 4.2 & -1.72 \\
\hline $\mathrm{Mg}-\mathrm{Ca}-0.5 \mathrm{Gd}$ & -1740.8 & 283.8 & -240.4 & 0.993 & 42.42 & 1.0 & -1.56 \\
\hline $\mathrm{Mg}-\mathrm{Ca}-1 \mathrm{Gd}$ & -2002.8 & 307.4 & -265.0 & 1.54 & 32.2 & 0.8 & -1.62 \\
\hline $\mathrm{Mg}-\mathrm{Ca}-1.5 \mathrm{Gd}$ & -1576.0 & 264.1 & -250.2 & 2.55 & 16.53 & 0.41 & -1.68 \\
\hline $\mathrm{Mg}-\mathrm{Ca}-2 \mathrm{Gd}$ & -1491.9 & 196.9 & -179.8 & 2.76 & 12.71 & 0.28 & -1.61 \\
\hline $\mathrm{Mg}-\mathrm{Ca}-3 \mathrm{Gd}$ & -1447.7 & 256.1 & -236.3 & 2.25 & 5.92 & 0.16 & -1.58 \\
\hline
\end{tabular}

The compounds formed on the surface after immersion was based on the alloys' main elements, especially magnesium and calcium oxides. At the beginning of the contact between the experimental alloys and the electrolytes, a protective oxide layer appeared on the surface and, for a certain period of time, provided protection against corrosion; the layer was generally formed from $\mathrm{Mg}(\mathrm{OH})_{2}$. The formation and growth of the $\mathrm{Mg}(\mathrm{OH})_{2}$ layer was followed by a hydrogen discharge, as directly observed by visual inspection. As a conclusion, the formed $\mathrm{Mg}(\mathrm{OH})_{2}$ layer cannot provide effective protection to the $\mathrm{Mg}$ substrate, at least not for a longer period of time. The $\mathrm{pH}$ of the solution varied with the chemical reactions that occurred on the surface as a basic general characteristic and sometimes, especially with the formation of $\mathrm{HCl}$, decreased due to the influence of acid formation.

The corrosion current $\left(J_{c o r r}\right)$ expresses the reduction value of the experimental materials in contact with an electrolyte solution. The corrosion density presented different values for the experimental alloys from $5.92 \mu \mathrm{A} / \mathrm{cm}^{2}$ to $170.11 \mu \mathrm{A} / \mathrm{cm}^{2}$ (Table 5).

The influence of the gadolinium element added to the magnesium-calcium alloy on the electro-corrosion resistance properties of the system is highlighted in Table 5. A reduction in the corrosion rate of up to 20 times with the addition of $3 \mathrm{wt} . \%$ of Gd was observed compared with the $\mathrm{Mg}-0.5 \mathrm{Ca}$-based experimental alloy, $\mathrm{Mg} \_0.5 \mathrm{Ca}$. In quantitative terms, the percentage of $\mathrm{Gd}$ significantly influenced the behavior of the alloy at values higher than $2 \mathrm{wt} . \%$ of Gd. It is known that both intermetallic compounds have a significant influence on the electro-corrosion resistance of $\mathrm{Mg}$-based materials $[48,49]$. The open circuit potential $(\mathrm{OCP})$ shows close values for all samples, decreasing with the elevated percentage of the alloying element. The open circuit potential (OCP) usually varies with the immersion time because of the changes in the nature of the sample's surface during its exposure to a corrosive medium. The lower OCP value in the case of $\mathrm{Mg}-\mathrm{Ca}-3 \mathrm{Gd}$ confirms the formation of a passivation layer on the sample's surface. This shows that the intermetallic compounds retain the cathodic reactions more than anodic, and positive ions have time to diffuse. The $\mathrm{Mg}-0.5 \mathrm{Ca}$ alloy had a more negative potential $(-3511.2 \mathrm{mV})$ than the $\mathrm{Mg}-\mathrm{Ca}-\mathrm{xGd}$ alloy $(-1447.7 \mathrm{mV})$, indicating that the addition of $\mathrm{Gd}$ shifted to a more noble direction, thus having a positive effect on the corrosion resistance of the alloys. It can be observed that the cathodic polarization in the $\mathrm{Mg}-0.5 \mathrm{Ca}-1 \mathrm{Gd}$ alloy was significantly higher than that of the $\mathrm{Mg}-0.5 \mathrm{Ca}-2 \mathrm{Gd}$, indicating that the corrosion potential $\left(E_{0}\right)$ was more negative in the alloy with reduced amounts of $\mathrm{Gd}$. It can also be seen that the anodic polarization curve of the $\mathrm{Mg}-\mathrm{Ca}-1 \mathrm{Gd}$ alloy was greater than that of the $\mathrm{Mg}-\mathrm{Ca}$ alloy. The lower $J_{\text {corr }}$, along with the longer anodized polarization curve and more negative $E_{0}$ results, demonstrates that the corrosion resistance was improved for the $\mathrm{Mg}-\mathrm{Ca}-\mathrm{Gd}$ alloy (Figure 5). The corrosion current density of the $\mathrm{Mg}-0.5 \mathrm{Ca}$ alloy was $170 \mu \mathrm{A} / \mathrm{cm}^{2}$, which is significantly higher than that on $\mathrm{Mg}-\mathrm{Ca}-3 \mathrm{Gd}\left(5.92 \mu \mathrm{A} / \mathrm{cm}^{2}\right)$. As a result, the formation of a specific phase, namely the $\alpha-\mathrm{Mg}$-based $\mathrm{Mg}_{5} \mathrm{Gd}$ solid solution had a higher influence on the corrosion behavior of the alloys. 

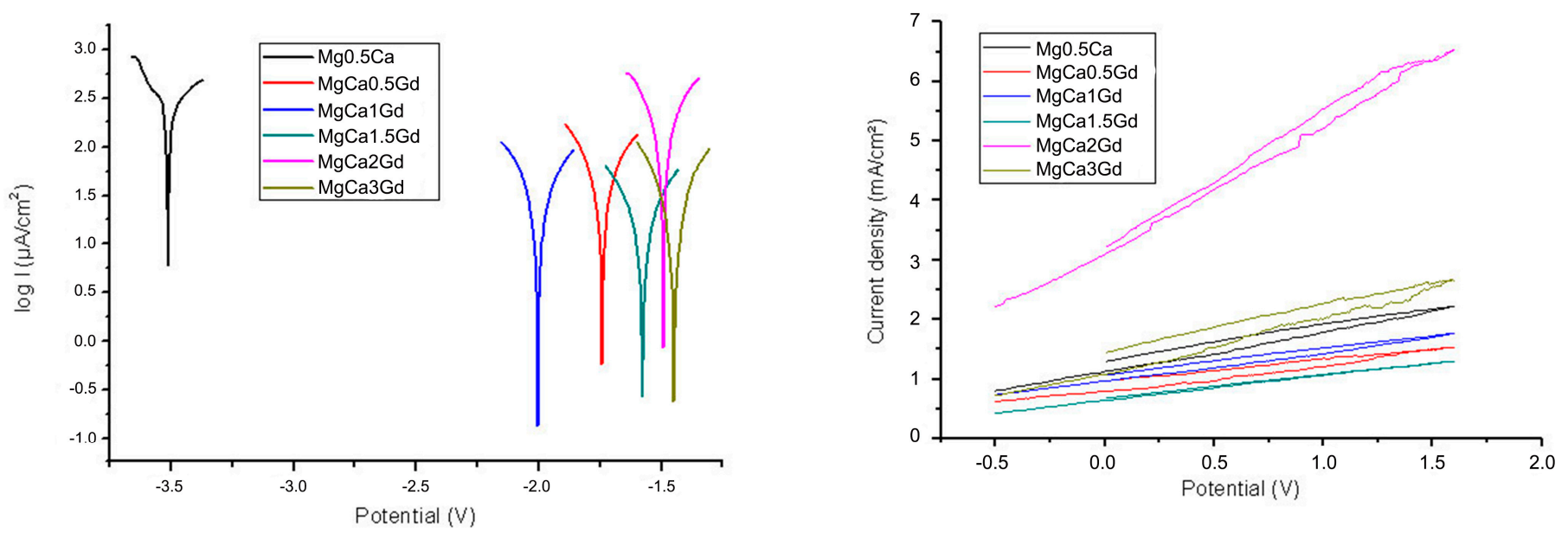

Figure 5. Tafel diagrams of $\mathrm{Mg}-0.5 \mathrm{Ca}-\mathrm{xY}$-based experimental alloys.

During cyclo-voltammetric sweeps (Figure 5) changes developed in the passive films and in the solution composition at the metal-electrolyte interface (e.g., hydroxide formation and $\mathrm{pH}$ increase), as well as development of the general corrosion form.

All specimens had a generally corroded surface, particularly due to linear and cyclic polarization tests. In all cases, in addition to the detachment of the material from the surface of the alloys, the growth of the different compounds took place through contact between the surface of the experimental materials and the electrolyte. Corrosion compounds appeared on the surface of magnesium-based alloys, exhibiting many micro-cracks and various morphological details.

The polarization cyclic curves present the generalized corrosion of the surface of all specimens. Cyclic voltammetry consists of scanning of the electrode potential in the positive direction up to a determined value for current or potential, after which, the scanning is immediately reversed towards more negative values until it reaches the initial potential; in some cases, this scanning is repeated to determine the modifications produced on the current-potential curve obtained by scanning. However, in our case, the cyclic voltammograms no longer show a hysteresis loop; the cathode branch of the voltammogram practically overlaps the anodic branch, except for a narrow potential range located in the immediate vicinity of the potential from which dissolution starts. This little "backwards" shift of the cathode branch may be explained by the modification of the specimens' surface following corrosion (as a consequence of corrosion, the metal surface increases, making the current density decrease). The very small area of the cyclic curve loop reflects an insignificant increase of zonal corrosion (pitting type).

Figure 6 shows SEM images of the surface of experimental Mg-0.5Ca-xGd after the electro-corrosion resistance test with different image magnification powers. A generalized corrosion surface is observed, covered with reaction compounds that passed from the electrolyte solution (SBF) to the surface.

In addition to the layer of magnesium oxide formed on the surface of the alloy, there were several different formations of compounds that could be oxides of other elements, carbonates or salts (sodium or potassium chlorides). The compounds that covered the alloy formed a layer that insulated the alloy from the electrolyte medium. Compounds formed on the surface had numerous cracks and fissures that confirm the instability of these compounds on the surface. Figure 6a shows the typical morphology of magnesium oxide. The compounds on the surface have different morphologies, which indicate the possibility of forming compounds with different chemical compositions. Figure $6 \mathrm{~b}$ shows the identification of the chemical elements that appear on the corroded surface of the Mg-0.5Ca-0.5Gd alloy. 

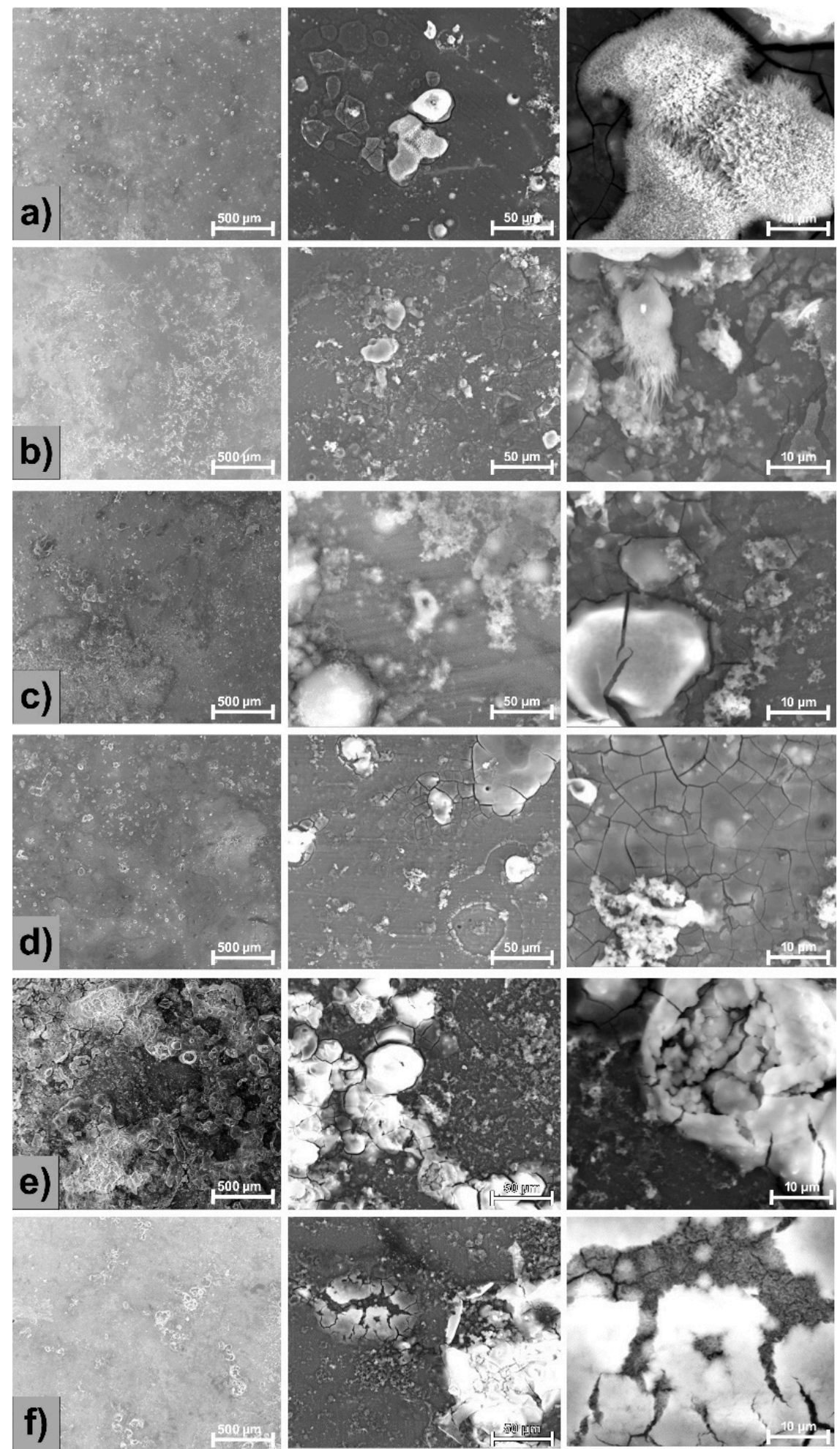

Figure 6. SEMs of the samples surfaces after electrochemical tests: (a) $\mathrm{Mg}-0.5 \mathrm{Ca}$; (b) $\mathrm{Mg}-0.5 \mathrm{Ca}-0.5 \mathrm{Gd}$; (c) $\mathrm{Mg}-0.5 \mathrm{Ca}-1 \mathrm{Gd} ;$ (d) Mg-0.5Ca-1.5Gd; (e) Mg-0.5Ca-2Gd; (f) Mg-0.5Ca-3Gd.

Surface oxidation in all cases was confirmed by the chemical composition determinations (Table 6) using the EDS detector (values are average of five determinations from $1-\mathrm{mm}^{2}$ areas). Sample $\mathrm{Mg}-\mathrm{Ca}-2 \mathrm{Gd}$ presents higher stability of the oxides on the surface and, together with samples $\mathrm{Mg}-\mathrm{Ca}-1.5 \mathrm{Gd}$ and $\mathrm{Mg}-\mathrm{Ca}-1 \mathrm{Gd}$, also has traces of chloride and sodium as salts or other compounds. 
Table 6. Elements identified on the Mg-0.5Ca-xGd alloys' surface after the electro-corrosion resistance tests.

\begin{tabular}{|c|c|c|c|c|c|c|c|}
\hline $\mathrm{Mg}-0.5 \mathrm{Ca}$ & $\begin{array}{l}\text { Chemical elements } \\
\text { Surface with oxides }\end{array}$ & $\begin{array}{c}\mathbf{M g} \\
\text { wt. } \% \\
81\end{array}$ & $\begin{array}{c}\text { Ca } \\
\text { wt. } \% \\
0.8\end{array}$ & $\begin{array}{c}\text { Gd } \\
\text { wt. } \% \\
-\end{array}$ & $\begin{array}{c}\text { O } \\
\text { wt. } \% \\
18.2\end{array}$ & $\begin{array}{c}\text { Cl } \\
\text { wt. } \% \\
-\end{array}$ & $\begin{array}{c}\mathbf{N a} \\
\text { wt.\% } \\
-\end{array}$ \\
\hline $\begin{array}{l}\mathrm{Mg}-0.5 \mathrm{Ca}- \\
0.5 \mathrm{Gd}\end{array}$ & $\begin{array}{l}\text { Chemical elements } \\
\text { Surface with oxides }\end{array}$ & $\begin{array}{c}\mathbf{M g} \\
\text { wt. } \% \\
70.5\end{array}$ & $\begin{array}{c}\text { Ca } \\
\text { wt. } \% \\
0.8\end{array}$ & $\begin{array}{c}\text { Gd } \\
\text { wt. } \% \\
0.8\end{array}$ & $\begin{array}{c}\text { O } \\
\text { wt. } \% \\
27.9\end{array}$ & $\begin{array}{c}\mathrm{Cl} \\
\text { wt. } \% \\
-\end{array}$ & $\begin{array}{c}\mathrm{Na} \\
\text { wt.\% } \\
-\end{array}$ \\
\hline $\begin{array}{c}\mathrm{Mg}-0.5 \mathrm{Ca}- \\
1 \mathrm{Gd}\end{array}$ & $\begin{array}{l}\text { Chemical elements } \\
\text { Surface with oxides }\end{array}$ & $\begin{array}{c}\mathbf{M g} \\
\text { wt. } \% \\
77.7\end{array}$ & $\begin{array}{c}\text { Ca } \\
\text { wt. } \% \\
1.1\end{array}$ & $\begin{array}{c}\text { Gd } \\
\text { wt. } \% \\
1.2\end{array}$ & $\begin{array}{c}\text { O } \\
\text { wt. } \% \\
18.7\end{array}$ & $\begin{array}{c}\mathrm{Cl} \\
\text { wt. } \% \\
-\end{array}$ & $\begin{array}{c}\mathbf{N a} \\
\text { wt. } \% \\
1.3\end{array}$ \\
\hline $\begin{array}{l}\mathrm{Mg}-0.5 \mathrm{Ca}- \\
1.5 \mathrm{Gd}\end{array}$ & $\begin{array}{l}\text { Chemical elements } \\
\text { Surface with oxides }\end{array}$ & $\begin{array}{c}\mathbf{M g} \\
\text { wt. } \% \\
72.2\end{array}$ & $\begin{array}{c}\text { Ca } \\
\text { wt. } \% \\
0.8\end{array}$ & $\begin{array}{c}\text { Gd } \\
\text { wt. } \% \\
0.8\end{array}$ & $\begin{array}{c}\text { O } \\
\text { wt. } \% \\
23.3\end{array}$ & $\begin{array}{c}\mathrm{Cl} \\
\text { wt. } \% \\
2.2\end{array}$ & $\begin{array}{c}\mathbf{N a} \\
\text { wt. } \% \\
0.6\end{array}$ \\
\hline $\begin{array}{c}\mathrm{Mg}-0.5 \mathrm{Ca}- \\
2 \mathrm{Gd}\end{array}$ & $\begin{array}{l}\text { Chemical elements } \\
\text { Surface with oxides }\end{array}$ & $\begin{array}{c}\mathbf{M g} \\
\text { wt. } \% \\
65.3\end{array}$ & $\begin{array}{c}\text { Ca } \\
\text { wt. } \% \\
0.9\end{array}$ & $\begin{array}{c}\text { Gd } \\
\text { wt. } \% \\
0.6\end{array}$ & $\begin{array}{c}\mathbf{O} \\
\text { wt. } \% \\
32.2\end{array}$ & $\begin{array}{c}\mathrm{Cl} \\
\text { wt. } \% \\
0.3\end{array}$ & $\begin{array}{c}\mathbf{N a} \\
\text { wt. } \% \\
0.7\end{array}$ \\
\hline $\begin{array}{c}\mathrm{Mg}-0.5 \mathrm{Ca}- \\
3 \mathrm{Gd}\end{array}$ & $\begin{array}{l}\text { Chemical elements } \\
\text { Surface with oxides }\end{array}$ & $\begin{array}{c}\text { Mg } \\
\text { wt.\% } \\
83.1\end{array}$ & $\begin{array}{c}\text { Ca } \\
\text { wt.\% } \\
0.5\end{array}$ & $\begin{array}{c}\text { Gd } \\
\text { wt. } \% \\
1.3\end{array}$ & $\begin{array}{c}\text { O } \\
\text { wt.\% } \\
15.1\end{array}$ & $\begin{array}{c}\mathbf{C l} \\
\text { wt. } \%\end{array}$ & $\begin{array}{c}\mathbf{N a} \\
\text { wt.\% }\end{array}$ \\
\hline
\end{tabular}

SD (determined for the main elements after 20 chemical composition analyses on the same area) are: Mg: \pm 1.1 Ca: $\pm 0.2 ; \mathrm{Gd}: \pm 0.1 ; \mathrm{O}: \pm 1.5 ; \mathrm{Cl}: \pm 0.1 ; \mathrm{Na}: \pm 0.1$.

The main elements identified (with percentages higher than $0.01 \%$ ) are: oxygen, magnesium, calcium and gadolinium. The elements calcium, gadolinium and chlorine appear, which implies the participation of these elements in two or more bonds characteristic of different compounds. The increase in Gd content at values greater than $2 \%$ is a success in terms of corrosion resistance, confirmed by the Tafel linear results. In the case of the 3\% $\mathrm{Gd}$ alloy, the presence of $\mathrm{O}, \mathrm{Na}, \mathrm{C}$ and $\mathrm{Cl}$ elements was identified on the surface by the interaction of the experimental alloy with the SBF electrolyte solution. The presence of chlorine-based salts is also noted.

\subsection{Cytocompatibility Study}

In the current study, the MTT test results for the cytocompatibility assessment of $\mathrm{Mg}-0.5 \mathrm{Ca}-\mathrm{xGd}$ experimental alloys are shown in Figure 7, calculated as percentages from the viability of the negative control (i.e., control wells). The results of Day 1 of co-incubation revealed that the level of cell viability varied in an increasing way and proportional to the increase in the percentage of $\mathrm{Gd}$ as the alloying element, being similar to the case of alloys with $2 \% \mathrm{Gd}$ and $3 \% \mathrm{Gd}(p>0.05)$, but significantly higher compared with the viability level results in the case of the other experimental samples $(p<0.05)$. The cytocompatibility profile recorded after 3 days of co-incubation with the studied alloys reached a similar level and showed that there were no statistically significant differences among all studied samples $(p>0.05)$ at 3 days. It was observed that with an increase in co-incubation time for up to 5 days, the cell viability profile registered an increase in the case of all alloys but remained significantly lower $(p<0.05)$ for alloys with $0.5 \% \mathrm{Gd}$ and $1 \% \mathrm{Gd}$. In addition, the results showed no significant differences in cell viability after 5 days for samples with a Gd quantity of $1.5 \%, 2 \%$ and $3 \%(p>0.05)$, similar to the $\mathrm{Mg}-\mathrm{Ca}$ control alloy. The MTT results seem to suggest the fact that increasing the percentage of gadolinium used for alloying did not affect the viability level in a dose-dependent manner (i.e., no significant differences among the 1.5, 2 and 3\% Gd-alloyed Mg-Ca alloys) and this could be due to an increase in the stability of alloys in a humid environment (as was detailed in the previous section; i.e., Electrochemical Corrosion Resistance Analysis) with a complex composition (such as culture medium or simulated biological fluids). The decreased level of viability after 1day of co-incubation of the cells with the alloy samples could be attributed to the degradation 
of the alloys immersed in the experimental culture medium [53], which has the immediate consequence of releasing hydrogen with a change in $\mathrm{pH}$ (i.e., subsequent alkalinization, as a consequence of an $\mathrm{Mg}^{2+}$-related anodic reaction by which $\mathrm{H}_{2} \mathrm{O}$ is reduced to $\mathrm{H}_{2}$ and $\mathrm{OH}^{-}$). As other authors have indicated, $\mathrm{Mg}$ alloy degradation events may harmfully affect the cell metabolism through ion bulk leakage from $\mathrm{Mg}$ alloys and subsequent precipitation of salts with an inhibitory or toxic influence, and by increasing of the osmolarity (as a result of alloy reactivity) which may lead to hyperosmotic shock [54]. It should be point out that because of $\mathrm{Mg}$ alloys' degradation depend on the microenvironment conditions [55], different corrosion/degradation events under particular biomedical scenarios (i.e., different flow and/or composition of biological fluids) can take place by affecting the surface chemistry of the implants. These facts are still to be proved by an ongoing in vivo study.

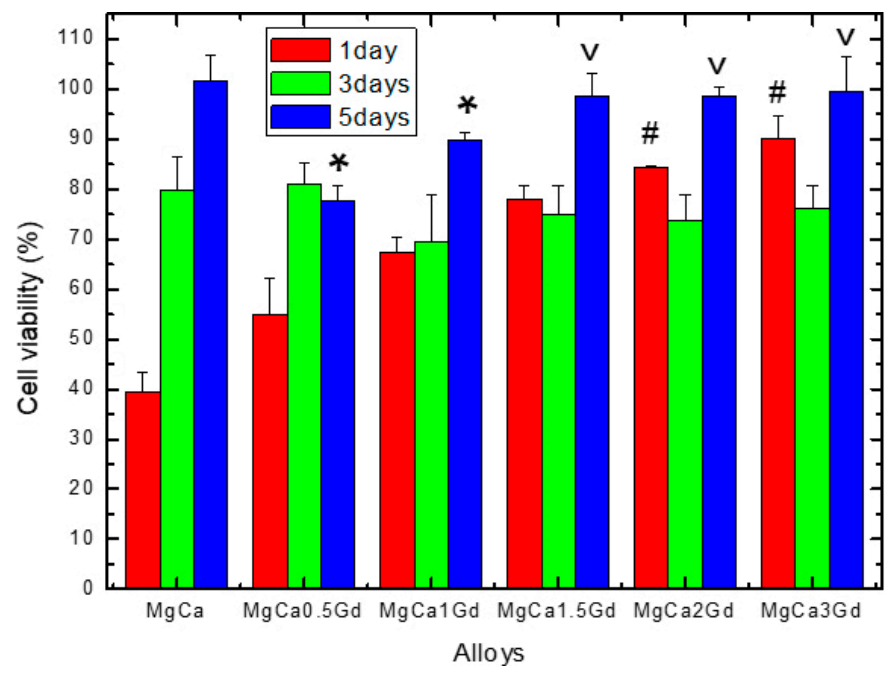

Figure 7. Cell viability vs. studied $\mathrm{Mg}-0.5 \mathrm{Ca}-\mathrm{xGd}$ samples: Effect of Gd alloying on cell viability after 1, 3, and 5 days of co-incubation. Results are shown as percent of the control wells' viability (i.e., negative control). $(\vee, \#)$ Not statistically significant $(p>0.05) ;\left({ }^{*}\right)$ statistically significant $(p<0.05)$.

Furthermore, the level of viability recorded at 3 days was $73-80 \%$ and, at 5 days, was 77-100\%, which permits us to consider (according to the ISO 10993-5 standard [56]) that the experimental samples do not appear to exhibit a long-term cytotoxic character. This is due to the continuous exposition of the cells to the sum of the abovementioned occurrences that occurred during the biodegradation of $\mathrm{Mg}$ alloys (i.e., exposure to $100 \%$ extracts for up to 5 days).

The registered viability profiles correlate with the results on the density and morphology of fibroblasts (Figure 8) co-incubated with the experimental samples for $24 \mathrm{~h}$ and 5 days, respectively. It has been shown that after $24 \mathrm{~h}$, the cell density in the case of the experimental alloys was lower than in the case of the control wells (i.e., negative control, containing only cultured cells without the Mg alloy sample). This finding is in agreement with the cell viability results, being confirmed by the data obtained after 5 days of co-incubation of the cells with the experimental alloys. In addition, different cell spreading was observed inside the wells, such as high density areas containing cells having an elongated appearance and a bipolar morphology, and low density areas (observed towards the center of the wells and around the inserted membrane), where the cells had a polygonal shape with extensive lamellipodia-like cytoplasmic processes. The cells' variable morphology maybe associated with the regional micro-environmental changes inside the wells concerning the $\mathrm{Ca}, \mathrm{Mg}$ and $\mathrm{Gd}$ ionic concentrations (as a result of the degradation of $\mathrm{Mg}$ alloys inside the insert), considering the associated structural role of calcium in the reorganization of cytoskeleton constituents [57], while magnesium accumulated up to a critical concentration could have an inhibitory effect [58]. 

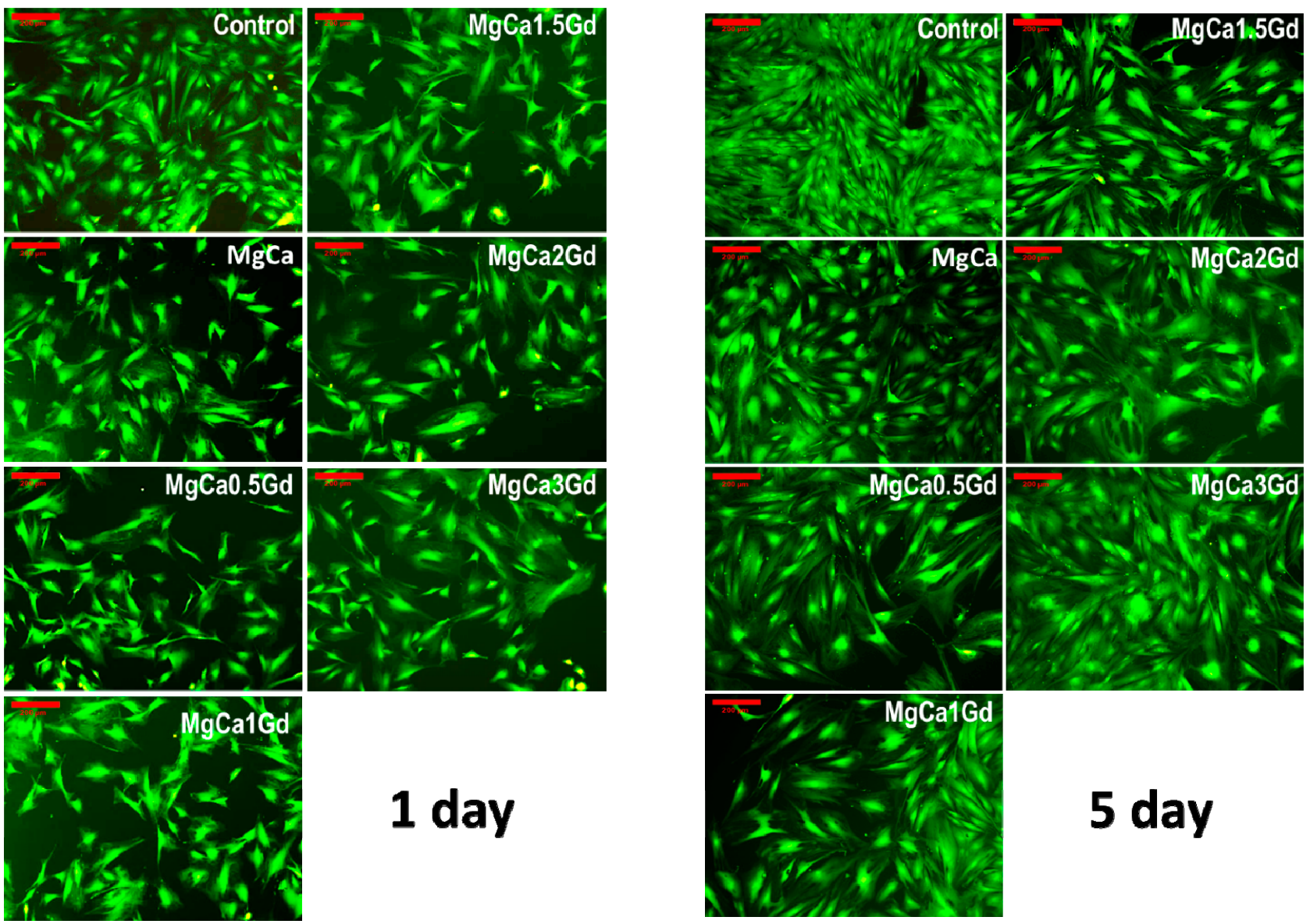

\section{1 day}

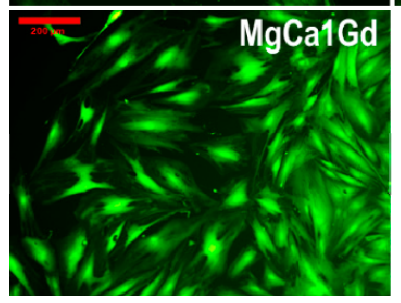

\section{5 day}

Figure 8. Fibroblastic cells' morphology evaluated by fluorescence microscopy after 1 and 5 days of co-incubation with the studied samples. Viable cells are stained in green as a result of calcein fluorescent dye's presence inside the cells. Bar: $200 \mu \mathrm{m}$.

\section{Conclusions}

In this article, five experimental biodegradable Mg-based alloys ( $\mathrm{Mg}-0.5 \mathrm{Ca}-0.5 \mathrm{Gd}$, $\mathrm{Mg}-0.5 \mathrm{Ca}-1 \mathrm{Gd}, \mathrm{Mg}-0.5 \mathrm{Ca}-1.5 \mathrm{Gd}, \mathrm{Mg}-0.5 \mathrm{Ca}-2 \mathrm{Gd}$ and $\mathrm{Mg}-0.5 \mathrm{Ca}-3 \mathrm{Gd})$ were analyzed. In summary, the authors highlighted the influence of $\mathrm{Gd}$ in a $\mathrm{Mg}-0.5 \mathrm{Ca}$ system from the point of view of microstructure, corrosion resistance and cell viability. Microstructural characterization results from optical and scanning electron microscopy and XRD analysis highlighted patterns of a refined polyhedrical shape of $\mathrm{Mg}$ grains, with cubic crystalline structures, due to $\mathrm{Gd}$ addition. The morphological aspects of $\mathrm{Gd}$ particles $\left(\mathrm{Mg}_{5} \mathrm{Gd}\right.$ - white compounds) seem to have an acicular or round aspect and at the Mg grains' limit, the $\mathrm{Mg}_{2} \mathrm{Ca}$ eutectic compound is formed due to $\mathrm{Ca}$ addition. The results on the degradation rate performed in a simulated body fluid solution highlighted low values and showed an area slightly affected by corrosion. The best results of electro-corrosion resistance were achieved by the $\mathrm{Mg}-0.5 \mathrm{Ca}-3 \mathrm{Gd}$, which showed a degradation rate of $0.28 \mathrm{~mm} / \mathrm{yr}$. Decreasing the Gd concentration led to increasing the corrosion rate up to $4.2 \mathrm{~mm} / \mathrm{yr}$ (0.5 wt.\%). The presented experimental samples highlighted very good cell viability at 3 days (73-80\% range) and at 5 days ( $77-100 \%$ range). Some low viability results were obtained for the experimental alloys $(0.5 \mathrm{wt} . \%-2 \mathrm{wt} . \% \mathrm{Gd})$ after $24 \mathrm{~h}$, a fact which should be attributed to the samples' reactivity leading to ion release from the alloys, $\mathrm{pH}$ and osmolarity increasing, and salt precipitation with toxic or inhibitory effects. Cell viability after 5 days was not significantly different for alloys with a Gd amount of $1.5 \%, 2 \%$ and $3 \%$ $(p>0.05)$ compared with the MgCa control alloy, so increasing the Gd alloying amount also improved the cytocompatibility of these alloys (as a consequence of improving the 
alloys' stability). The study will continue with in vivo analysis, in order to see the exact behavior of the experimental alloys implanted within laboratory animals.

Author Contributions: Conceptualization, B.I., C.M., N.C. and M.D.V.; methodology, C.M., R.C. and M.D.V.; software, B.I. and M.D.V.; validation, C.M., R.C., N.C. and M.D.V.; formal analysis, O.D.P.; investigation, B.I., R.C. and M.D.V.; resources, C.M. and N.C.; data curation, B.I. and M.D.V.; writing-original draft preparation, B.I., R.C. and M.D.V.; writing-review and editing, C.M., R.C. and M.D.V.; visualization, N.C.; supervision, C.M. and N.C. project administration, C.M.; funding acquisition, C.M. All authors have read and agreed to the published version of the manuscript.

Funding: This work was supported by a grant from the Romanian Ministery of Research and Innovation, CCCDI-UEFISCDI, project number PN-III-P1-1.2-PCCDI-2017-0239/60PCCDI 2018, within PNCDI III.

Institutional Review Board Statement: Not applicable.

Informed Consent Statement: Not applicable.

Data Availability Statement: Not applicable.

Conflicts of Interest: The authors declare no conflict of interest.

\section{References}

1. Ali, Y.; Qiu, D.; Jiang, B.; Pan, F.; Zhang, M.-X. Current research progress in grain refinement of cast magnesium alloys: A review article. J. Alloys Compd. 2015, 619, 639-651. [CrossRef]

2. Song, J.; She, J.; Chen, D.; Pan, F. Latest research advances on magnesium and magnesium alloys worldwide. J. Magnes. Alloy. 2020, 8, 1-41. [CrossRef]

3. Kiani, F.; Wen, C.; Li, Y. Prospects and strategies for magnesium alloys as biodegradable implants from crystalline to bulk metallic glasses and composites-A review. Acta Biomater. 2020, 103, 1-23. [CrossRef] [PubMed]

4. Höhn, S.; Virtanen, S.; Boccaccini, A.R. Protein adsorption on magnesium and its alloys: A review. Appl. Surf. Sci. 2019, 464, 212-219. [CrossRef]

5. Yazdimamaghani, M.; Razavi, M.; Vashaee, D.; Moharamzadeh, K.; Boccaccini, A.R.; Tayebi, L. Porous magnesium-based scaffolds for tissue engineering. Mater. Sci. Eng. 2017, 71, 1253-1266. [CrossRef] [PubMed]

6. Mario, C.D.; Griffiths, H.; Goktekin, O.; Peeters, N.; Verbist, J.; Bosiers, M.; Deloose, K.; Heublein, B.; Rohde, R.; Kasese, V.; et al. Drug-eluting bioabsorbable magnesium stent. J. Interv. Cardiol. 2004, 17, 391-395. [CrossRef] [PubMed]

7. Zartner, P.; Cesnjevar, R.; Singer, H.; Weyand, M. First successful implantation of a biodegradable metal stent into the left pulmonary artery of a preterm baby. Catheter. Cardiovasc. Interv. 2005, 66, 590-594. [CrossRef] [PubMed]

8. Waksman, R.; Pakala, R.; Kuchulakanti, P.K.; Baffour, R.; Hellinga, D.; Seabron, R.; Tio, F.O.; Wittchow, E.; Hartwig, S.; Harder, C.; et al. Safety and efficacy of bioabsorbable magnesium alloy stents in porcine coronary arteries. Catheter. Cardiovasc. Interv. 2006, 68, 607-617. [CrossRef]

9. Lim, G.B. Interventional cardiology: DREAMS of a bioabsorbable stent coming true. Nat. Rev. Cardiol. 2013, 10, 120. [CrossRef]

10. Heublein, B.; Rohde, R.; Kaese, V.; Niemeyer, M.; Hartung, W.; Haverich, A. Biocorrosion of magnesium alloys: A new principle in cardiovascular implant technology. Heart 2003, 89, 651-656. [CrossRef]

11. Panahi, Z.; Tamjid, E.; Rezaei, M. Surface modification of biodegradable AZ91 magnesium alloy by electrospun polymer nanocomposite: Evaluation of in vitro degradation and cytocompatibility. Surf. Coat. Technol. 2020, 386, 125461. [CrossRef]

12. Toong, D.W.Y.; Ng, J.C.K.; Huang, Y.; Wong, P.E.H.; Leo, H.L.; Venkatraman, S.S.; Ang, H.Y. Bioresorbable metals in cardiovascular stents: Material insights and progress. Materialia 2020, 12, 100727. [CrossRef]

13. Witte, F.; Hort, N.; Vogt, C.; Cohen, S.; Kainer, K.U.; Willumeit, R.; Feyerabend, F. Degradable biomaterials based on magnesium corrosion. Curr. Opin. Solid State Mater. Sci. 2008, 12, 63-72. [CrossRef]

14. Waizy, H.; Seitz, J.M.; Reifenrath, J.; Weizbauer, A.; Bach, F.-W.; Lindenberg, A.M.; Denkena, B.; Henning, W. Biodegradable magnesium implants for orthopedic applications. J. Mater. Sci. 2013, 48, 39-50. [CrossRef]

15. Song, G.L.; Atrens, A. Corrosion Mechanisms of Magnesium Alloys. Adv. Eng. Mater. 1999, 1, 11-33. [CrossRef]

16. Zheng, Y.F.; Gu, X.N.; Witte, F. Biodegradable metals. Mater. Sci. Eng. R. Rep. 2014, 77, 1-34. [CrossRef]

17. Wu, G.; Wang, C.; Sun, M.; Ding, W. Recent developments and applications on high-performance cast magnesium rare-earth alloys. J. Magnes. Alloy. 2020. [CrossRef]

18. Zhang, J.; Liu, S.; Wu, R.; Hou, L.; Zhang, M. Recent developments in high-strength Mg-RE-based alloys: Focusing on Mg-Gd and Mg-Y systems. J. Magnes. Alloy. 2018, 6, 277-291. [CrossRef]

19. Liu, J.; Bian, D.; Zheng, Y.; Chu, X.; Lin, Y.; Wang, M.; Lin, Z.; Li, M.; Zhang, Y.; Guan, S. Comparative in vitro study on binary Mg-RE (Sc, Y, La, Ce, Pr, Nd, Sm, Eu, Gd, Tb, Dy, Ho, Er, Tm, Yb and Lu) alloy systems. Acta Biomater. 2020, 102, 508-528. [CrossRef] 
20. Tekumalla, S.; Seetharaman, S.; Almajid, A.; Gupta, M. Mechanical Properties of Magnesium-Rare Earth Alloy Systems: A Review. Metals 2015, 5, 1-39. [CrossRef]

21. Feyerabend, F.; Fischer, J.; Holtz, J.; Witte, F.; Willumeit, R.; Drucker, H.; Vogt, C.; Hort, N. Evaluation of short-term effects of rare earth and other elements used in magnesium alloys on primary cells and cell lines. Acta Biomater. 2010, 6, 1834-1842. [CrossRef] [PubMed]

22. Hort, N.; Huang, Y.; Fechner, D.; Störmer, M.; Blawert, C.; Witte, F.; Vogt, C.; Drücker, H.; Willumeit, R.; Kainer, K.U.; et al. Magnesium alloys as implant materials-Principles of property design for Mg-RE alloys. Acta Biomater. 2010, 6, 1714-1725. [CrossRef] [PubMed]

23. Gao, L.; Chen, R.S.; Han, E.H. Effects of rare-earth elements Gd and Y on the solid solution strengthening of mg alloys. J. Alloys Compd. 2009, 481, 379-384. [CrossRef]

24. Peng, Q.; Wu, Y.; Fang, D.; Meng, J.; Wang, L. Microstructures and properties of melt-spun and as-cast Mg-20Gd binary alloy. J. Rare Earths 2006, 24, 466-470. [CrossRef]

25. Nodooshan, H.R.J.; Liu, W.C.; Wu, G.H.; Rao, Y.; Zhou, C.X.; He, S.P.; Ding, W.J.; Mahmudi, R. Effect of Gd content on microstructure and mechanical properties of Mg-Gd-Y-Zr alloys under peak-aged condition. Mater. Sci. Eng. A 2014, 615, 79-86. [CrossRef]

26. Xiaobo, Z.; Zhixin, B.; Zhangzhong, W.; Yujuan, W.; Yajun, X. Effect of LPSO structure on mechanical properties and corrosion behavior of as-extruded GZ51K magnesium alloy. Mater. Lett. 2016, 163, 250-253.

27. Myrissa, A.; Braeuer, S.; Martinelli, E.; Willumeit-Römer, R.; Goessler, W.; Weinberg, A.M. Gadolinium accumulation inorgans of Sprague-Dawley ${ }^{\circledR}$ rats after implantation of abiodegradable magnesium-gadolinium alloy. Acta Biomater. 2017, 48, 521. [CrossRef]

28. Xuenan, G.; Yufeng, Z.; Yan, C.; Shengping, Z.; Tingfei, X. In vitro corrosion and biocompatibility of binary magnesium alloys. Biomaterials 2009, 30, 484-498. [CrossRef]

29. Wang, X.; Dong, L.H.; Li, J.T.; Li, X.L.; Ma, X.L.; Zheng, Y.F. Microstructure, mechanical property and corrosion behavior of interpenetrating $(\mathrm{HA}+\beta-\mathrm{TCP}) / \mathrm{MgCa}$ composite fabricated by suction casting. Mater. Sci. Eng. C 2013, 33, 4266-4273. [CrossRef]

30. Salahshosor, M.; Li, C.; Liu, Z.Y.; Fang, X.Y.; Guo, Y.B. Surface integrity and corrosion performance of biomedical magnesiumcalcium alloy processed by hybrid dry cutting-finish burnishing. J. Mech. Behav. Biomed. Mater. 2018, 78, 246-253. [CrossRef]

31. Staiger, M.P.; Pietak, A.M.; Huadmai, J.; Dias, G. Magnesium and its alloys as orthopedic biomaterials: A review. Biomaterials 2006, 27, 1728-1734. [CrossRef] [PubMed]

32. Zeng, R.C.; Dietzel, W.; Witte, F.; Hort, N.; Blawert, C. Progress and challenge for magnesium alloys as biomaterials. Adv. Eng. Mater. 2008, 10, B3-B14. [CrossRef]

33. Li, Z.; Gu, X.; Lou, S.; Zheng, Y. The development of binary Mg-Ca alloys for use as biodegradable materials within bone. Biomaterials 2008, 29, 1329-1344. [CrossRef] [PubMed]

34. Atrens, A.; Song, G.L.; Liu, M.; Shi, Z.; Cao, F.; Dargusch, M.S. Review of recent developments in the field of magnesium corrosion. Adv. Eng. Mater. 2015, 17, 400-453. [CrossRef]

35. Yu, H.D.; Zhang, Z.Y.; Win, K.Y.; Chan, J.; Teoh, S.H.; Han, M.Y. Bioinspired fabrication of 3D hierarchical porous nanomicrostructures of calcium carbonate for bone regeneration. Chem. Commun. 2010, 35, 6578. [CrossRef] [PubMed]

36. Maradze, D.; Capel, A.; Martin, N.; Lewis, M.P.; Zheng, Y.; Liu, Y. In vitro investigation of cellular effects of magnesium and magnesium-calcium alloy corrosion products on skeletal muscle regeneration. J. Mater. Sci. Technol. 2019, 35, 2503-2512 [CrossRef]

37. Schwander, M.; Leu, M.; Stumm, M.; Dorchies, O.M.; Ruegg, U.T.; Schittny, J.; Müller, U. $\beta 1$ Integrins Regulate Myoblast Fusion and Sarcomere Assembly. Dev. Cell 2003, 4, 673-685. [CrossRef]

38. Zeng, R.C.; Qi, W.C.; Cui, H.Z.; Zhang, F.; Li, S.Q.; Han, E.H. In vitro corrosion of as-extruded Mg-Ca alloys-The influence of Ca concentration. Corros. Sci. 2015, 96, 23-31. [CrossRef]

39. Salahshoor, M.; Guo, Y. Biodegradable Orthopedic Magnesium-Calcium (MgCa) Alloys, Processing, and Corrosion Performance. Materials 2012, 5, 135-155. [CrossRef]

40. Jeong, Y.S.; Kim, W.J. Enhancement of mechanical properties and corrosion resistance of Mg-Ca alloys through microstructural refinement by indirect extrusion. Corros. Sci. 2014, 82, 392-403. [CrossRef]

41. Master Alloys Supplier Website. Available online: http:/ /www.hbnewmaterial.com/supplier-129192-master-alloy (accessed on 15 June 2020).

42. Lupescu, S.; Istrate, B.; Munteanu, C.; Minciuna, M.G.; Focsaneanu, S.; Earar, K. Characterization of Some Master Mg-X System (Ca, Mn, Zr, Y) Alloys Used in Medical Applications. Rev. Chim. 2017, 68, 1408-1413. [CrossRef]

43. Istrate, B.; Munteanu, C.; Lupescu, S.; Chelariu, R.; Vlad, M.D.; Vizureanu, P. Electrochemical Analysis and In Vitro Assay of Mg-0.5Ca-xY Biodegradable Alloys. Materials 2020, 13, 3082. [CrossRef] [PubMed]

44. Mosmann, T. Rapid colorimetric assay for cellular growth and survival: Application to proliferation and cytotoxicity assays. J. Immunol. Methods 1983, 65, 55-63. [CrossRef]

45. Vlad, M.D.; Valle, L.J.; Poeată, I.; Barracó, M.; López, J.; Torres, R.; Fernández, E. Injectable iron-modified apatitic bone cement intended for kyphoplasty: Cytocompatibility study. J. Mater. Sci. Mater. Med. 2008, 19, 3575-3583. [CrossRef]

46. Vlad, M.D.; Valle, L.J.; Poeată, I.; López, J.; Torres, R.; Barracó, M.; Fernández, E. Biphasic calcium sulfate dihydrate/iron-modified alpha-tricalcium phosphate bone cement for spinal applications: In vitro study. Biomed. Mater. 2010, 5, 025006. [CrossRef] [PubMed] 
47. Liu, M.; Schmutz, P.; Uggowitzer, P.; Song, G.; Atrens, A. The influence of Y (Y) on the corrosion of Mg-Y binary alloys. Corros. Sci. 2010, 52, 3687-3701. [CrossRef]

48. Tong, X.; Zai, L.; You, G.; Wu, H.; Wen, H.; Long, S. Effects of bonding temperature on microstructure and mechanical properties of diffusion-bonded joints of as-cast Mg-Gd alloy. Mater. Sci. Eng. A 2019, 767, 138408. [CrossRef]

49. Kang, L.; Liang, Z.; Guohua, W.; Wencai, L.; Wenjian, D. Effect of Y and Gd content on the microstructure and mechanical properties of Mg-Y-RE alloys. J. Magnes. Alloy. 2019, 7, 345-354.

50. Junxiu, C.; Lili, T.; Xiaoming, Y.; Ke, Y. Effect of minor content of Gd on the mechanical and degradable properties of as-cast Mg-2Zn-xGd-0.5Zr alloys. J. Mater. Sci. Technol. 2019, 35, 503-511.

51. Sudholz, A.D.; Gusieva, K.; Chen, X.B.; Muddle, B.; Gibson, M.; Birbilis, N. Electrochemical behaviour and corrosion of Mg-Y alloys. Corros. Sci. 2011, 53, 2277-2282. [CrossRef]

52. Südholz, A.D.; Kirkland, N.T.; Buchheit, R.G.; Birbilis, N. Electrochemical Properties of Intermetallic Phases and Common Impurity Elements in Magnesium Alloys. Electrochem. Solid-State Lett. 2011, 14, C5-C7. [CrossRef]

53. Li, Z.; Sun, S.; Chen, M.; Fahlman, B.D.; Liu, D.; Bi, H. In vitro and in vivo corrosion, mechanical properties and biocompatibility evaluation of MgF2-coated Mg-Zn-Zr alloy as cancellous screws. Mater. Sci. Eng. C 2017, 75, 1268-1280. [CrossRef] [PubMed]

54. Gilles, R.; Belkhir, M.; Compere, P.; Libioulle, C.; Thiry, M. Effect of high osmolarity acclimation on tolerance to hyperosmotic shocks in L929 cultured cells. Tissue Cell 1995, 27, 679-687. [CrossRef]

55. Esmaily, M.; Svensson, J.E.; Fajardo, S.; Birbilis, N.; Frankel, G.S.; Virtanen, S.; Arrabal, R.; Thomas, S.; Johansson, L.G. Fundamentals and advances in magnesium alloy corrosion. Prog. Mater. Sci. 2017, 89, 92-193. [CrossRef]

56. ISO 10993-5:2009-Biological Evaluation of Medical Devices-Part 5: Tests for In Vitro Cytotoxicity. Available online: http: // nhiso.com/wp-content/uploads/2018/05/ISO-10993-5-2009.pdf (accessed on 25 September 2020).

57. Mbele, G.O.; Deloulme, J.C.; Gentil, B.J.; Delphin, C.; Ferro, M.; Garin, J.; Takahashi, M.; Baudier, J. The zinc and calcium-binding S100B interacts and co-localizes with IQGAP1 during dynamic rearrangement of cell membranes. J. Biol. Chem. 2002, 277, 49998-50007. [CrossRef] [PubMed]

58. Yang, L.; Hort, N.; Laipple, D.; Höche, D.; Huang, Y.; Kainer, K.U.; Willumeit, R.; Feyerabend, F. Element distribution in the corrosion layer and cytotoxicity of alloy Mg-10Dy during in vitro biodegradation. Acta Biomater. 2013, 9, 8475-8487. [CrossRef] [PubMed] 